\title{
Federal Habeas Corpus and State Procedural Default: An Abstention-Based Interest Analysis
}

\author{
Stephanie Dest $\dagger$
}

Congress extended the writ of habeas corpus to the claims of state petitioners in 1867. ${ }^{1}$ This act was part of a great shift in the American federal system, a shift that displaced the states as the primary protectors of constitutional rights. "As a result of the new structure of law that emerged in the post-Civil War era-and especially of the Fourteenth Amendment, which was its centerpiece-the role of the Federal Government as a guarantor of basic federal rights against state power was clearly established."3 The change was an especially pronounced one for the federal judiciary which, as a result of the structural reversal, became the primary tool for vindicating federal rights. ${ }^{4}$

This structural reversal, or Reconstruction federalism, has

† B.A. 1986, The University of Chicago; J.D. Candidate 1989, The University of Chicago.

1 The Habeas Corpus Act of Feb 5, 1867, ch 28 \$ 1, 14 Stat 385, codified as amended at 28 USC $\$ \$ 2241-2255$ (1982). The federal courts were originally granted habeas corpus jurisdiction over the claims of federal prisoners only. The Judiciary Act of 1789, § 14, 1 Stat 73.

${ }^{2}$ Under the original federal plan the states were given the responsibility of protecting the individual from abuses of governmental power. The Bill of Rights, for example, was adopted as a response to the fear that the expansive power of the newly formed federal government would pose a threat to individual liberty. See, for example, Raoul Berger, Federalism: The Founders' Design 178 (U Okla, 1987).

s Mitchum v Foster, 407 US 225, 238-239 (1972).

- Felix Frankfurter \& James M. Landis, The Business of the Supreme Court 65 (MacMillan, 1928). See also the statements of Representative Dawes during the debates on the Civil Rights Act of 1871 (which implemented the Fourteenth Amendment):

The first remedy proposed by this bill is a resort to the courts of the United States. Is that a proper place in which to find redress for any such wrongs? If there be power to call into the courts of the United States an offender against these rights, privileges and immunities, and hold him to an account there, ... I submit ... that there is no tribunal so fitted, where equal and exact justice would be more likely to be meted out in temper, in moderation, in severity if need be, but always according to the law and the fact, as that great tribunal of the Constitution.

Cong Globe, 42d Cong, 1st Sess 476 (April 5, 1871). Note, however, that Congress did not extend general federal-question jurisdiction to the federal courts until 1875. Act of March 3, $1875 \S 1$, 18 Stat 470 . Hence, the congressional choice to use the federal courts as a protector of the Civil War Amendments was a deliberate and unusual one. 
thrust state and federal interests into apparent conflict with respect to the federal enforcement of the habeas corpus writ, a conflict accentuated by the Warren Court's expansive push to protect civil liberties. Because of this tension, and a history of judicial discretion in the interpretation of the habeas corpus writ, the Supreme Court has struggled to articulate a substantive and consistent solution to the problem presented by the federal review of habeas corpus claims that are defaulted in state court. Where the Court has felt the need to change its analyses it has done so-even though the statutory grant of jurisdiction has remained largely unchanged ${ }^{5}$ - by reasoning that it has always employed interpretive freedom in habeas corpus cases to "back and fill" its employment of the writ. ${ }^{6}$

A procedural default occurs in the habeas corpus context when a state prisoner has "exhaust[ed] his state remedies without obtaining any decision on the merits of his federal constitutional claim because he has failed to comply with state procedural rules on how the claim must be raised." Such defaults usually involve traditional "make it or waive it" defenses, such as contemporaneous objection rules, in which appeals are forfeited if not made in a timely fashion. The procedural default/habeas corpus issue has not lent itself easily to doctrinal analysis since its resolution, as characterized by the Supreme Court, is thought necessarily to involve a conflict between two important governmental interests: providing a federal forum for the vindication of constitutional rights and reinforcing the procedural integrity of state criminal justice systems. ${ }^{8}$

${ }^{5}$ For the text of the modern statute, see 28 USC $\S 2254$ (1982) which provides, in relevant parts:

(a) The Supreme Court, a Justice thereof, a circuit judge, or a district court shall entertain an application for a writ of habeas corpus in behalf of a person in custody pursuant to the judgment of a State court only on the ground that he is in custody in violation of the Constitution or laws or treaties of the United States.

(b) An application for a writ of habeas corpus in behalf of a person in custody pursuant to the judgment of a State court shall not be granted unless it appears that the applicant has exhausted the remedies available in the courts of the State, or that there is either an absence of available State corrective process or the existence of circumstances rendering such process ineffective to protect the rights of the prisoner.

(c) An applicant shall not be deemed to have exhausted the remedies available in the courts of the State, within the meaning of this section, if he has the right under the law of the state to raise, by any available procedure, the question presented.

${ }^{-}$Fay $v$ Noia, 372 US 391, 411-412 (1963).

7 Charles Alan Wright, Arthur R. Miller \& Edward H. Cooper, 17A Federal Practice and Procedure: Jurisdiction $\$ 4266$ at 433 (West, $2 \mathrm{~d}$ ed 1988). Procedural defaults are also called "abortive state proceedings." The terms are essentially synonymous.

${ }^{3}$ See Reed $v$ Ross, 468 US 1, 10 (1984). 
The current law governing procedural defaults was articulated by the Supreme Court in Wainwright $v$ Sykes. ${ }^{9}$ In Wainwright, the Court found the state procedural interest paramount, holding that the failure to comply with a state procedural rule will bar federal habeas corpus review unless the defendant can show cause for his failure to comply with the rule in question and actual prejudice occasioned by any default.

This "cause and prejudice" rule is premised largely upon the belief that a state procedural rule deserves a fair amount of respect "both for the fact that it is employed by a coordinate jurisdiction within the federal system and for the many interests which it serves in its own right."10 This reasoning, however, virtually ignores the countervailing federal interests that are at the heart of Reconstruction federalism and that underlie the availability of federal habeas corpus jurisdiction over the claims of state prisoners. In addition, this analysis incorrectly characterizes the governmental interests involved as being directly in conflict. The governmental interests are in tension, but they do not actually conflict since the habeas corpus statute, by its own terms, trumps the state interests.

In 1986, Justice Brennan, dissenting in Murray v Carrier, attempted to provide a more coherent framework for the analysis of procedurally defaulted habeas claims by asserting that "the withholding of federal habeas jurisdiction for certain procedurally defaulted claims is a form of abstention." "II Justice Brennan had used this characterization many years previously in Fay $v$ Noia ${ }^{12}$, where he described certain early federal habeas cases in which the Court declined to interfere with an ongoing state proceeding as fashioning "a doctrine of abstention, whereby full play would be allowed the States in the administration of their criminal justice without prejudice to federal rights enwoven in the state proceedings." This comment discusses the merits of Justice Brennan's position, using general abstention principles as a framework for analyzing whether federal courts should decline to review state procedurally defaulted habeas corpus claims.

Section I of the comment traces the development of the Su-

- 433 US 72 (1977).

${ }^{10}$ Id at 88.

1447 US 478, 518 (1986) (Brennan dissenting). See also Kuhlmann $v$ Wilson, 477 US 436, $465 \mathrm{n} 3$ (1986) (Brennan dissenting).

12372 US at 391.

1s Id at 419 and $n$ 28, noting that this doctrine, "with refinements," was eventually codified as the exhaustion requirement of 28 USC $\$ 2254$ (b). 
preme Court's "cause and prejudice" standard for evaluating state procedurally defaulted habeas corpus claims. Section II outlines a number of federal abstention doctrines and posits a model of federal abstention based on interest analysis. Section III characterizes the various federal and state interests involved in the state procedural default of federal claims and measures those interests against developed abstention standards.

In concluding, the comment argues that, based upon an interest analysis dictated by federal doctrine, abstention is unwarranted in the context of procedurally defaulted habeas corpus claims. Any governmental interest, state or federal, in fostering the procedural integrity of criminal trials does not overcome the heavy presumption against a federal court's "virtually unflagging obligation"14 to exercise civil rights jurisdiction granted by Congress. Extension of the habeas corpus writ to the claims of state prisoners was designed to ensure the availability of a federal forum for the review of federal claims that might otherwise be treated with hostility by state courts. Given the importance of this interest, the federal courts do not have sufficient reason to balance away the federal policy implicit in this jurisdictional command, even to ensure that the integrity of state procedural rules will not be undermined.

\section{Evolution of the "Cause and Prejudice" Standard}

As noted above, the procedural default of a habeas corpus claim occurs when a state prisoner fails to comply with a state procedural rule, the consequence of which is that his federal claim never gets heard in state court. The procedural default/habeas corpus problem is thought to implicate two important, and competing, governmental interests: providing a federal forum for the vindication of constitutional rights and reinforcing the procedural integrity of state criminal justice systems. Characterized this way, it is difficult, if not impossible, for the federal courts to satisfy both interests at the same time.

If a federal court, for example, were to lend support to a state procedural rule by declining to hear federal claims that were raised improperly in state court, possible infringements of a prisoner's constitutional rights may go unheard-and uncorrected. If, on the other hand, a federal court were to hear federal claims that had not been properly presented to a state court, the federal court

14 Colorado River Water Cons. Dist. v United States, 424 US 800, 817 (1976). 
might be placed in the position of undermining the integrity of a state's criminal justice process and wasting scarce judicial resources. In Fay $v$ Noia, ${ }^{15}$ the Supreme Court attempted to resolve definitively this question of "under what circumstances, if any, the failure of a state prisoner to comply with a state procedural requirement, as a result of which the state courts decline to pass on the merits of his federal defense, bars subsequent resort to the federal courts for relief on habeas corpus."16

Previous to Fay, the question of whether federal habeas corpus review was available over state procedurally defaulted habeas corpus claims was analyzed under the "independent and adequate" state ground doctrine of federal jurisdiction. The independent and adequate state ground doctrine originated in the landmark case of Murdock $v$ Memphis. ${ }^{17}$ In Murdock, the Supreme Court held that a federal court did not have appellate jurisdiction to review a state case-even if the case presented a federal question-as long as there was an independent and adequate state ground that supported the state court's decision. The holding in Murdock, however, only applied to state substantive law, not to the enforcement of state procedural rules. The Murdock Court left open the question of whether a procedural default constituted an "independent and adequate" state ground, thereby possibly eliminating the availability of either direct or collateral federal review.

The Supreme Court answered this question in the affirmative in Brown $v$ Allen, holding that the "failure to use a state's available remedy, in the absence of some interference or incapacity ... bars federal habeas corpus."18 The Brown opinion noted specifically that "the state's procedure for relief must be employed in order to avoid the use of federal habeas corpus as a matter of procedural routine to review state criminal rulings."19

In Irvin $v$ Dowd, ${ }^{20}$ the Supreme Court, rather than directly applying the rule in Brown, avoided using the adequate state ground analysis in the procedural default context. The Irvin majority evaded the issue by reading an ambiguous state court decision as "resting the judgment on the holding that the petitioner's constitutional claim is without merit,"

is 372 US at 391.

18 Id at 399.

1787 US 590 (1875).

18344 US 443, 487 (1953).

10 Id at 487.

${ }^{20} 359$ US 394 (1959).

21 Id at 403. 
dural default constituted an adequate state ground. According to the Irvin majority, the state court had ruled "that the petitioner's constitutional claim [was] without merit." ${ }^{22}$ Hence, the Court ruled that there had been no procedural default. Four dissenters in Irvin, however, believed that an adequate state procedural ground sufficient to bar direct review by the Supreme Court was also sufficient to bar habeas corpus review. Because the Irvin majority appeared to back away from the holding in Brown, the question of how to analyze procedurally defaulted habeas corpus claims was left unsettled.

The Supreme Court resolved the procedural default/habeas corpus question, at least temporarily, in Fay $v$ Noia, rejecting as "unsound in principle, as well as not supported by authority, the suggestion that the federal courts are without power to grant habeas relief ... because of a procedural default furnishing an adequate and independent ground of state decision." ${ }^{23}$ In a clear move away from Brown, ${ }^{24}$ the Court said that the adequate state ground doctrine was "not to be extended to limit the power granted the federal courts under the federal habeas statute"25 since the "adequate state-ground rule [was] a function of the limitations of $a p$ pellate review."26

In Fay, the Supreme Court categorically refused to concede jurisdictional significance to a state procedural default, asserting instead that the habeas jurisdiction of the federal courts was established simply by the allegation of unconstitutional restraint; of detention simpliciter. ${ }^{27}$ The Supreme Court found support for its conclusion in three sources: (1) in the nature of the writ of habeas corpus at common law; (2) in the language and purpose of the original Habeas Corpus Act of February 5, 1867; and (3) in a century of Supreme Court precedent. ${ }^{28}$ The Fay Court also engaged in a form of interest balancing, weighing the state interest in the finality of state criminal decisions against the federal policy "that federal constitutional rights of personal liberty shall not be denied

22 Id.

23372 US at 434.

24 While the Court did not explicitly overrule Brown, it said: "To the extent that any decisions of this Court may be read to suggest a standard of discretion in federal habeas corpus proceedings different from what we lay down today, such decisions shall be deemed overruled to the extent of any inconsistency." Id at $439 \mathrm{n} 44$.

25 Id at 399.

26 Id at 429 (emphasis in original).

27 Id at 426,430 (emphasis in original).

28 Id at 426 . 
without the fullest opportunity for plenary federal judicial review." ${ }^{29}$ The Court went on to explain that:

Congress in 1867 sought to provide a federal forum for state prisoners having constitutional defenses by extending the habeas corpus powers of the federal courts to their constitutional maximum. Obedient to this purpose, we have consistently held that federal court jurisdiction is conferred by the allegation of an unconstitutional restraint and is not defeated by anything that may occur in the state court proceedings. State procedural rules plainly must yield to this overriding federal policy. ${ }^{30}$

In Fay, the state interest in barring the federal habeas review of procedural defaults was characterized as procedural. The federal interest, however, was characterized as both procedural and substantive; as the enforcement of substantive federal law in a federal forum. Thus, under this characterization, the combination of federal interests trumped the state procedural interests.

The Court in Fay noted, however, that although the independent and adequate state ground doctrine did not limit the scope of federal habeas corpus jurisdiction, the federal courts still possessed the judicial discretion to "deny relief to an applicant who has deliberately by-passed the orderly procedure of the state courts and in so doing has forfeited his state court remedies." 31 This "limited" discretion was based largely upon the recognition "that the exigencies of federalism warrant a limitation whereby the federal judge has the discretion to deny relief to one who has deliberately sought to subvert or evade the orderly adjudication of his federal defenses in the state courts." 32 The Supreme Court derived the judicial discretion to decline review of federal claims that had been intentionally defaulted in the state court from several sources: (1) from discretion allegedly inherent in the habeas corpus statute, since the statute allows federal judges, after granting the writ and holding a hearing of appropriate scope, to "dispose of the matter as law and

28 Id at 424 .

${ }^{\text {so Id }}$ at 426-27 (emphasis added). Compare the dissenting opinion of Justice Harlan (in which Justices Clark and Stewart joined) which complained that through the Fay decision "the Court has turned its back on history and struck a heavy blow at the foundations of our federal system." Id at 449. Justice Harlan believed that a procedural default constituted an independent and adequate state ground. Thus, for him, the federal courts in such cases were without the power to take jurisdiction of a habeas claim under such circumstances.

s1 Id at 438.

${ }^{32}$ Id at 433. 
justice require"; ${ }^{33}$ (2) from the equitable nature of the habeas corpus writ; and (3) from precedent, in particular from the exercise of judicial discretion that had been used to develop the habeas exhaustion requirement now codified at 28 USC $\S 2254$ (b) (1982). ${ }^{34}$

As soon as the Supreme Court adopted the Fay rule, it began to back away from it. This shift was nothing new to habeas corpus jurisprudence. The Supreme Court has always felt fairly free to rethink its habeas positions and to use discretion in its interpretation of the scope of the writ as well as in its assertion of collateral habeas corpus jurisdiction..$^{35}$ But this perception of judicial freedom has not produced settled habeas corpus doctrine, a fact noted with candor by the Court in Fay: "We do not suggest that this Court has always followed an unwavering line in its conclusions as to the availability of the Great Writ. Our development of the law of federal habeas corpus has been attended, seemingly, with some

${ }^{33} 28$ USC § 2243 (1982).

34 Fay, 372 US at 438. This reliance on precedent is a form of bootstrapping. The Supreme Court's assertion of judicial discretion in another context of habeas corpus jurisdiction does not mean that the exercise of such discretion was legitimate when used. Nor does it necessarily support the inference that Congress's acquiescence in, and eventual codification of, the exhaustion requirement changes congressional intent with respect to the scope of federal habeas jurisdiction generally (as viewed in the context of Reconstruction federalism) or in the procedural default context particularly.

ss Historically, the writ of habeas corpus was available only for jurisdictional defects. See Sir Frederick Pollock \& Frederick William Maitland, 2 The History of English Law 586 (Cambridge, 2d ed 1968). The decision of even a corrupt court, for example, would be upheld so long as the court in question had jurisdiction to decide the case. Professor Hart described the original use of the writ nicely:

The habeas corpus court, of course, could inquire into the competence of the tribunal-that is, its jurisdiction-to enter the judgment of conviction as well as into the question whether the judgment which it had entered authorized the detention. But once these inquiries were satisfied the function of the writ . . . was at an end. If the rules distributing authority to make decisions had been complied with, in other words, an antecedent violation of the rules governing the decision to be made was immaterial. Henry M. Hart, Jr., Foreword: The Time Chart of the Justices, 73 Harv L Rev 84, 103-104 (1959).

For an account of the American colonial history of the writ see William S. Church, Habeas Corpus §§ 38-45 (Bancroft-Whitney, 2d ed, 1893); A.H. Carpenter, Habeas Corpus in the Colonies, $8 \mathrm{Am}$ Hist Rev 18 (1902). Since colonial times, the Court has continuously expanded the scope of the writ. Now, habeas corpus review extends to all constitutional and civil rights claims and is not confined merely to claims of unconstitutional restraint. See Brown v Allen, 344 US 443, 465 (1953) (claims under the Fourteenth Amendment).

For the seminal work on the historical expansion of the writ of habeas corpus in the United States see Curtis R. Reitz, Federal Habeas Corpus: Impact of an Abortive State Proceeding, 74 Harv L Rev 1315 (1961) and for works examining the Supreme Court's use of history in analyzing the scope of the habeas corpus writ see, for example, Dallin H. Oaks, Legal History in the High Court-Habeas Corpus, 64 Mich L Rev 451 (1966); Lewis Mayers, The Habeas Corpus Act of 1867: The Supreme Court as Legal Historian, $33 \mathrm{U}$ Chi L Rev 31 (1965). 
backing and filling." ${ }^{36}$

The Court's movement away from the "deliberate bypass" rule promulgated in Fay began with its decision in Davis $v$ United States. ${ }^{37}$ In Davis, a federal prisoner sought to challenge, for the first time on federal habeas corpus review, the composition of the grand jury that had indicted him. The Supreme Court interpreted the congressional intent behind the adoption of Rule 12(b)(2) of the Federal Rules of Criminal Procedure, which requires that such challenges be made "by motion before trial," to control on collateral habeas review. ${ }^{38}$ Hence, the Supreme Court ruled that a federal procedural default-absent a showing of cause for relief from the waiver (a standard embodied in the text of the rule) and actual prejudice occasioned by any default (an implied standard)-precluded federal collateral habeas corpus review..$^{39}$

Because the Court in Davis did not deal with the effect of a failure to follow a state procedural rule, it effectively left the Fay holding intact. In Francis $v$ Henderson, ${ }^{40}$ however, the Supreme Court departed dramatically from the Fay Court's "deliberate bypass" rule. In Francis, the Court extended the Davis "cause and prejudice" requirements of Federal Rule 12(b)(2) to cover the state procedural default of the same kind of claim that had been defaulted in Davis (i.e., the failure to challenge grand jury composition by motion before trial). The Court reasoned that, although the federal courts had power to assert federal habeas jurisdiction in such a case, "considerations of comity and concerns for the orderly administration of criminal justice" ${ }^{\text {41 }}$ require that the Court give no "greater preclusive effect to procedural defaults by federal defendants than to similar defaults by state defendants. To hold otherwise would reflect an anomalous and erroneous view of federalstate relations." ${ }^{24}$ Thus, a concern for a comity grounded in federalism runs through both the Fay and Francis procedural default tests. In Francis, however, the facilitation of an ordered system of

so 372 US at $411-412$.

${ }^{37} 411$ US 233 (1973).

s8 It is important to note, however, that congressional intent with respect to the extension of the rule's preclusive effect to collateral review was not clear. Rather, the Supreme Court found "it inconceivable that Congress ... intended to perversely negate the Rule's purpose by permitting an entirely different but much more liberal requirement of waiver in federal habeas proceedings." In the absence of direct intent, the Court interpreted the "necessary effect" of the congressional adoption of the Rule. Id at 242.

s9 Id at $242,244-45$.

10425 US 536 (1976).

42 Id at 538-39.

42 Id at 542, quoting Kaufman v United States, 394 US 217, 228 (1969). 
criminal justice is coupled with comity concerns to create a set of state interests that trump the federal policy implicit in the extension of collateral habeas corpus jurisdiction to the claims of state petitioners.

In Wainwright $v$ Sykes, the Court extended its application of "cause and prejudice" test developed in Davis and Francis to state contemporaneous objection rules. ${ }^{43}$ The Wainwright Court found that the Fay "deliberate bypass" standard did not accord enough respect to the state's contemporaneous objection rule, a procedural rule which deserved deference "both for the fact that [the rule] is employed by a coordinate jurisdiction within the federal system and for the many interests which it serves in its own right."44

In Wainwright, the Court also seemed to change its mind with respect to the appropriateness of the "independent and adequate state ground" analysis of procedural defaults that was rejected in Fay. The Wainwright Court held that the defendant's "failure to timely object to [the] admission [of his confession] amounted to an independent and adequate state procedural ground which would have prevented direct review [to the Supreme Court]."45 The Supreme Court, however, went on in Wainwright to decide the case based on the state interests in having contemporaneous-objection rules enforced noting that "there was power in the federal courts to entertain an application in such cases."46

The most startling difference between the Fay and Wainwright analyses lies in the divergent ways the Supreme Court characterized and weighed the different sovereign interests involved in the case of a state procedurally defaulted habeas corpus claim. In Fay, the importance of having a federal forum for the enforcement of federal rights trumped the reinforcement of state procedural rules. But, under such a balance, the federal courts still had the discretion to decline to take jurisdiction of federal claims that had been intentionally defaulted at the state level. In Wainwright,

43433 US 72 (1977). There is still some doubt as to whether Fay was specifically overruled by Wainwright. In Wainwright, the Supreme Court said only that "[i]t is the sweeping language of Fay $v$ Noia, going far beyond the facts of the case eliciting it, which we today reject." 433 US at 87-88. The Court also noted in a footnote that it had "no occasion today to consider the Fay rule as applied to the facts there confronting the Court" and specifically left the question for "another day." Id at $88 \mathrm{n} 12$.

14433 US at 88. In Murray v Carrier, 477 US 478, 496 (1986), the Court noted, however, that "[i]n an extraordinary case, where a constitutional violation has probably resulted in the conviction of one who is actually innocent a federal habeas court may grant the writ even in the absence of a showing of cause for the procedural default."

4543 US at 87.

48433 US at 84. 
however, the federal policy of ensuring the enforcement of federal rights in a federal forum was outweighed by comity concerns attending collateral review by a coordinate jurisdiction and by state interests, such as finality and reliability, thought to be fostered by the rigid enforcement of state procedural rules.

The Supreme Court in Wainwright did not want to waive state procedural defaults, in part, because it thought nonenforcement would tend to detract from "the trial of a criminal case in state court as a decisive and portentous event." 47 Given the Francis analysis as precedent, the Wainwright Court had little trouble recharacterizing and reweighing the various interests involved, noting, as it had in Fay, the "Court's historic willingness to overturn or modify its earlier views of the scope of the writ, even where that statutory language authorizing judicial action has remained unchanged." 48 This judicial discretion has given the Supreme Court little need to fully explain its changing and growing emphases upon the importance of federalism and the integrity of state criminal procedure. ${ }^{48}$

In Wainwright, the Court deliberately left the meaning of "cause and prejudice" to be defined in future decisions. ${ }^{50}$ Subsequent cases have refined the standard. ${ }^{51}$ For purposes of providing a coherent structure to the procedural default/habeas corpus problem, the most important of these cases is Murray $v$ Carrier. ${ }^{52}$ In Murray, the Supreme Court held that "cause for a procedural default on appeal ordinarily requires a showing of some external impediment preventing counsel from constructing or raising the claim." Thus, attorney inadvertence does not constitute "cause"

47433 US at 90.

48 Id at 81 .

19 For commentary about the Supreme Court's lack of explanation in this area, see Louis M. Seidman, Factual Guilt and the Burger Court: An Examination of Continuity and Change in Criminal Procedure, 80 Colum L Rev 436, 465-67 (1980); Richard A. Micheal, The New Federalism and the Burger Court's Deference to the States in Federal Habeas Corpus Proceedings, 64 Iowa L Rev 233, 268-69 (1979).

so 433 US at 91 .

${ }^{31}$ See Engle v Isaac, 456 US 107 (1982); United States v Frady, 456 US 152 (1982); Reed $v$ Ross, 468 US 1 (1984); Murray v Carrier, 477 US 478 (1986). The Supreme Court has recently granted certiorari in a case relating to the preclusive effect of a procedural default in cases where a state ignores its own procedural default and decides the merits of a petitioner's constitutional claim(s) anyway. Harris v Reed, 822 F2d 684 (7th Cir 1987), cert granted in part, $108 \mathrm{~S} \mathrm{Ct} 1107$ (1988). This case has some important implications for the procedural default problem, since if a state waives its own procedural default it must not value the integrity of its procedural rules very highly.

$s 2477$ US 478 (1986).

ss Id at 492. 
under this holding. The Murray opinion also emphasized many of the same state procedural concerns, on comity grounds, that the Court had found so persuasive in Wainwright, noting that the costs of federal review to the state included a reduction in the finality of litigation and the frustration of " 'both the States' sovereign power to punish offenders and their good-faith attempts to honor constitutional rights.' " 54

The "cause and prejudice" rule validated in Wainwright $v$ Sykes is a prudential limitation on the exercise of federal jurisdiction, grounded in comity and the exercise of judicial discretion. The rule is designed to minimize federal/state tensions occasioned by the collateral review of state court decisions. Since the procedural default/habeas corpus problem raises federalism issues thought to require judicial deference in the name of comity, Justice Brennan argued in Murray that "the withholding of federal habeas jurisdiction for certain procedurally defaulted habeas claims is a form of abstention."

The federal abstention doctrines, as developed to date, are also judicially created, comity based prudential limitations on the exercise of federal jurisdiction. Federal abstention, however, is a more doctrinally mature area of federal jurisdiction than the relatively discrete problem of procedural default in the habeas corpus context. ${ }^{.6}$ As a form of abstention, the "cause and prejudice" test of Wainwright should be analyzed by the comparatively well structured parameters of federal abstention doctrine, by principles normally used to analyze and guide the allocation of judicial power between state and federal governments. The federal abstention doctrines are outlined below.

\section{The Federal Abstention Doctrines}

Since 1941, the Supreme Court has created a series of "abstention" doctrines, grounded in equity, through which the federal courts decline to exercise their statutory jurisdiction when the ex-

${ }^{34}$ Id at 487, quoting Engle $v$ Isaac, 456 US 107, 128 (1982).

Bs 477 US at 518 (Brennan dissenting).

s6 There are genuine doubts, however, as to the legitimacy of the federal abstention doctrines themselves. For competing views, see David L. Shapiro, Jurisdiction and Discretion, 60 NYU L Rev 543 (1985); Martin H. Redish, Abstention, Separation of Powers and the Limits of the Judicial Function, 94 Yale L J 71, 74-75, 110-114 (1984); Michael Wells, Why Professor Redish is Wrong About Abstention, $19 \mathrm{Ga} L \mathrm{Rev} 1097,1122-25$ (1985). Since the abstention doctrines have been accepted by the federal courts (and, arguably, by Congress), however, this comment proceeds under an assumption of their viability, if not their validity. 
ercise of such jurisdiction appears unwise. Though the Court has identified several types of federal abstention, they are all premised on two basic themes: a desire to avoid premature constitutional adjudication and a regard for preserving the appropriate lines of federal/state relations. Throughout the development of all the abstention doctrines, however, there has been considerable disagreement as to when state interests rise to such a level of importance that federal courts should defer to them in the name of proper federal/ state relations.

The Supreme Court first articulated the concept of federal abstention in Railroad Comm'n v Pullman Co. ${ }^{57}$, in which a Texas railway regulation was challenged on grounds of racial discrimination under both state and federal law. The meaning of the relevant Texas statute-namely, the scope of "unjust discrimination"- had not been definitively interpreted by the state supreme court. Thus, the Supreme Court in Pullman "abstained" from hearing the case, reasoning that

[i]n this situation a federal court of equity is asked to decide an issue by making a tentative answer which may be displaced tomorrow by a state adjudication. The reign of law is hardly promoted if an unnecessary ruling of a federal court is thus supplanted by a controlling decision of a state court. The resources of equity are equal to an adjustment that will avoid the waste of a tentative decision as well as the friction of a premature constitutional adjudication. ${ }^{58}$

The Pullman Court intended federal abstention to be an equitable doctrine "appropriate to our federal system whereby the federal courts, 'exercising a wise discretion,' restrain their authority because of 'scrupulous regard for the rightful independence of state governments' and for the smooth working of the federal judiciary." The Court recognized that " $[t]$ his use of equitable powers is a contribution of the courts in furthering the harmonious relation between state and federal authority without the need of rigorous congressional restriction on those powers." beginning, abstention has been a judge made doctrine that operates, in the name of federalism, as a prudential limitation on fed-

${ }^{57} 312$ US 496 (1941).

ss Id at 500 (citations omitted).

s2 Id at 501, citing Cavanaugh $v$ Looney, 248 US 453, 457 (1919) and DiGiovanni v Camden Ins. Assn., 296 US 64, 73 (1935).

so Id at 501 (emphasis added). 
eral jurisdiction.

In Burford $v$ Sun Oil Co. ${ }^{61}$, the Supreme Court articulated another form of federal abstention, also grounded in comity and federalism. In Burford, the plaintiff brought a diversity suit in federal court to challenge the validity of a state administrative order that regulated the production of oil and natural gas within the state. Because the conservation and regulation of these resources involved complex technical issues, and because the state had provided for thorough judicial review, in part by specialized courts, a plurality of the Court held that a federal court having jurisdiction over a suit to enjoin the enforcement of a state administrative order

may, in its sound discretion ... 'refuse to enforce or protect legal rights, the exercise of which may be prejudicial to the public interest'; for it 'is in the public interest that federal courts of equity should exercise their discretionary power with proper regard for the rightful independence of state governments in carrying out their domestic policy. ${ }^{62}$

In practice, this means that the federal courts must be careful not to interfere with state administrative schemes for fear of making technical errors on state regulatory questions, and for fear of unduly intruding into state affairs. ${ }^{63}$

Justice Frankfurter dissented from the plurality opinion in Burford on the grounds that the congressional premise of the statutory (diversity) jurisdiction at issue "is that the possibility of unfairness against outside litigants is to be avoided by providing the neutral forum of a federal court." 64 By abstaining, he reasoned, "[ $t]$ he Court today is in effect withdrawing this grant of jurisdiction in order to avoid the possible unfairness against state interests in the federal courts. That which Congress created to assure impartiality of adjudication is now destroyed. . .."65

The Supreme Court expanded the doctrine of abstention in Younger $v$ Harris, ${ }^{68}$ where it held that federal courts, barring exceptional circumstances, cannot enjoin pending state criminal

eI 319 US 315,318 (1943).

${ }^{62}$ Id at 317-18, citing United States v Dern, 289 US 352, 360 (1933) and Pennsylvania v Williams, 294 US 176, 185 (1935) (emphasis added).

${ }^{63}$ See Lea Brilmayer, An Introduction to Jurisdiction in the Federal System 166 (Michie, 1986). Compare Meredith $v$ Winter Haven, 320 US 228 (1943).

B4 319 US at 345 (Frankfurter dissenting).

as Id.

${ }^{86} 401$ US 37 (1971). 
prosecutions. The Younger decision outlined the foundations of federal abstention, grounding the doctrine in the "basic functions of the Judicial Branch of the National Government"6z as well as in the dictates of federalism:

The precise reasons for this longstanding public policy against federal court interference with state court proceedings has never been specifically identified but the primary sources of the policy are plain. One is the basic doctrine of equity jurisprudence that courts of equity should not act ... when the moving party has an adequate remedy at law and will not suffer irreparable injury if denied equitable relief ... This underlying reason for restraining courts of equity from interfering with criminal prosecutions is reinforced by an even more vital consideration, the notion of "comity," that is, a proper respect for state functions, a recognition of the fact that the entire country is made up of a Union of separate state governments, and a continuance of the belief that the National Government will fare best if the States and their institutions are left free to perform their separate functions in their separate ways. ${ }^{68}$

Justice Douglas dissented in Younger, presenting arguments similar to those made by Justice Frankfurter in his Burford dissent. Given the Younger context, Douglas grounded his argument in the history of Reconstruction federalism itself:

[w] hatever the balance of the pressures of localism and nationalism prior to the Civil War, they were fundamentally altered by the war. The Civil War Amendments made civil rights a national concern. Those amendments, especially \& 5 of the Fourteenth Amendment, cemented the change in American federalism brought on by the war. Congress immediately commenced to use its new powers to pass legislation .... [T] he Reconstruction statutes, including the enlargement of federal jurisdiction, represent a later view of American federalism. ${ }^{69}$

The structural changes wrought by the Reconstruction Amendments animate the general dispute about the propriety of federal abstention with respect to the exercise of civil rights juris-

\footnotetext{
${ }^{67}$ Id at 53 .

68 Id at 43-44 (emphasis added).

ov Id at 61 (citation omitted).
} 
diction. ${ }^{70}$ In Harrison $v$ N.A.A.C.P ${ }^{71}$ a case involving state statutes enacted in direct contravention of Brown $v$ Board of Education, ${ }^{72}$ the majority held that the federal district court should have abstained from deciding the state issues in the case until the state courts had been afforded a reasonable opportunity to decide them. ${ }^{73}$

The dissent argued that abstention was improper when the plaintiff challenged statutes intended to inhibit racial integration. Clinging strongly to the premises of Reconstruction federalism, Justice Douglas, joined by Justice Brennan and Chief Justice Warren, argued that "[w]hen used widespread, [abstention] dilutes the stature of the Federal District Courts, making them secondary tribunals in the administration of justice under the Federal Constitution."74 Such dilution was improper, the dissent believed, because the availability of federal review over constitutional claims was meant to provide uniform and authoritative federal law and because deference to state policy bent on the nullification of federal rights was unwarranted. ${ }^{75}$

The Supreme Court's focus on comity as the most essential component in the balance of federal/state interests for federal abstention purposes has allowed to Court to expand the equitable doctrine of abstention to cover suits seeking damages as well as those seeking equitable relief. ${ }^{76}$ Wright, Miller, and Cooper have

${ }^{\text {s0 }}$ For arguments against the propriety of federal abstention when certain important federal and constitutional rights are at stake, see Herbert Wechsler, Federal Jurisdiction and the Revision of the Judicial Code, 13 L \& Contemp Probs 216, 230 (1948)(arguing that federal law wins in the procedural default context, not because the state law/rule is unimportant, but because the state interest is outweighed by greater factors of national concern); ALI Study of the Division of Jurisdiction Between State and Federal Courts (official Draft 1969) proposed $\S 1371(\mathrm{~g})$. For a list of federal cases in which the federal courts have refused to abstain from hearing important civil rights cases see Julie A. Davies, Pullman and Burford Abstention: Clarifying the Roles of State and Federal Courts in Constitutional Cases, 20 UC Davis L Rev 1, 17 n 83 (1986).

${ }^{71} 360$ US 167 (1959).

32347 US 483 (1954).

${ }^{23} 360$ US at 176-177.

74 Id at 180 (Douglas dissenting).

${ }^{25}$ Id at 182-84. For a more specific account of the change in federalism that occurred during Reconstruction see notes 2-4 above. For additional support of the concept of Reconstruction federalism and the congressional intent to use the writ of habeas corpus in aid of enforcing the Reconstruction Amendments see Charles Warren, 2 The Supreme Court in United States History 465 (Little Brown, 1923). For a more restrained view of history here compare Lewis Mayers, The Habeas Corpus Act of 1867: The Supreme Court as Legal Historian, 33 U Chi L Rev 31 (1965); Paul M. Bator, Finality in Criminal Law and Federal Habeas Corpus for State Prisoners, 76 Harv L Rev 441 (1963).

${ }^{76}$ See Louisiana P. \& L. Co. v Thibodaux City, 360 US 25 (1959); Clay v Sun Insurance Office, 363 US 207 (1960); United Gas v Ideal Cement Co., 369 US 134 (1962); 
noted with approval that considerations of comity and federalism are "too important to be made dependent on ancient distinctions about the powers of the several courts at Westminster Hall, and the ability of a federal court to defer to a state in a proper case ought not to depend on whether the case is thought of as 'legal' or 'equitable.' "77

There has been considerable disagreement among courts and scholars as to how many kinds of federal abstention there are. ${ }^{78}$ The number of abstention doctrines, however, makes little difference since classification of the abstention doctrines is simply an exercise in taxonomy that depends upon variations in procedural posture, factual content, and the complexity of state interests. ${ }^{79}$ Regardless of how abstention is divided, "the basic interests involved remain fundamentally the same: these are the interests of comity and federalism, and they wend their way through the cases in all the permutations which a litigious society can generate."80

From all the above, it is possible to assemble a general model of federal abstention. Because federal abstention acts to restrict congressionally mandated jurisdiction, application of the doctrine is exceptional and should be invoked only where significant state interests outweigh corresponding federal interests:

Fornaris v Ridge Tool Co., 400 US 41 (1970). See also Michael H. Cardozo, Choosing and Declaring State Law: Deference to State Courts Versus Federal Responsibility, 55 Nw U L Rev 419 (1960).

77 Wright, Miller \& Cooper, 17A Jurisdiction $\S 4241$ at 17-18 (cited in note 7). See Beach v Rome Trust Co., 269 F2d 367, 373-374 (2d Cir 1959). Compare Liberty Curtin Concerned Parents v Keystone Central School Dist., 81 FRD 590 (MD Pa 1978).

In Louisiana P. \& L. Co. $v$ City of Thibodaux, 360 US at 28, however, the Supreme Court also emphasized that the eminent domain action involved in the case was a special and peculiar kind of common law action that was analogous to an equitable proceeding. The Supreme Court has recently taken Younger further. See Ohio Civil Rights Commission v Dayton Christian Schools, 477 US 619 (1986) (Younger abstention is proper because the enforcement of state sex discrimination claims is a sufficiently important state interest and because an adequate opportunity to raise federal constitutional claims was provided at the state level); Pennzoil v Texaco, 481 US 1 (1987) (Younger abstention is inappropriate where federal claims have not been presented to the state courts and where it is impossible to determine whether state law actually raises the issues in question).

${ }^{78}$ See, for example, Ohio Bureau of Employment Services $v$ Hodory, 431 US 471, 477 (1977) (identifying Younger and Pullman abstention as the two primary types of abstention); Colorado River Water Cons. Dist. $v$ United States, 424 US 800, 814-816 (1976)(identifying three types of abstention). Wright, Miller \& Cooper divide abstention into four categories. See Wright, Miller \& Cooper, 17A Jurisdiction $\$ 4241$ at 28 (cited in note 7). For cases recognizing four abstention doctrines, see Muskegon Theatres, Inc. $v$ City of Muskegon, 507 F2d 199, 204 n 19 (6th Cir 1974); Koehler v Ogilvie, 53 FRD 98, 103 (ND Ill 1971), aff'd 405 US 906 (1972).

70 See Wright, Miller \& Cooper, 17A Jurisdiction $\S 4241$ at 25 n 66 (cited in note 7).

${ }^{80}$ Chemical Bank $v$ City of Brandon, 562 F Supp 704, 706 (D Or 1983). 
Abstention from the exercise of federal jurisdiction is the exception, not the rule. 'The doctrine of abstention, under which a District Court may decline to exercise or postpone the exercise of its jurisdiction, is an extraordinary and narrow exception to the duty of a District Court to adjudicate a controversy properly before it. Abdication of the obligation to decide cases can be justified under this doctrine only in the exceptional circumstances where the order to the parties to repair to the State court would clearly serve an important countervailing interest. ${ }^{\text {'1 }}$

The premise of federal abstention, a doctrine that tries to minimize federal/state tensions occasioned by the availability of federal review, is comity - a respect for state interests out of deference to state sovereignty. But, the degree of respect due state interests must be determined by the relative strengths and merits of the state and federal interests involved. Hence, abstention is premised on a form of governmental interest analysis.

\section{The Application of Federal Abstention Standards to State Procedurally Defaulted Habeas Corpus Claims}

The "cause and prejudice" test of Wainwright $v$ Sykes allows federal courts, within their discretion and in the name of comity, to decline habeas corpus jurisdiction in cases of state procedural default. It is thus a form of abstention and, as such, should be tested against developed abstention standards to determine whether such deference to state interests is either necessary or appropriate in the procedural default/habeas corpus context. An abstention-based interest analysis of state procedurally defaulted habeas corpus claims must evaluate, compare, and balance the interests of comity and federalism against the need to vindicate federal constitutional rights in a federal forum.

As noted in the previous section, there has long been debate about the legitimacy of abstention in contexts where state prejudices are thought to run high. The dissents in Burford, Harrison, and Younger all make points about the importance of the availability of federal jurisdiction in contexts where state biases have long been regarded as a threat to justice. The federal diversity jurisdiction at issue in Burford was designed to counter a state preference for its own citizens in suits between its own citizens and

${ }^{81}$ Colorado River, 424 US at 813, quoting County of Allegheny v Frank Mashuda Co., 360 US 185, 188-189 (1959) (emphasis added). 
citizens of another state. In Harrison the problem was the state legislature's nullification of civil rights laws. In Younger, hostility to the exercise of unpopular constitutional rights served as a backdrop for determining the propriety of enjoining a pending state criminal proceeding. Similarly, a mistrust of state court processes lies behind the availability of federal habeas corpus jurisdiction over the claims of state petitioners.

Given the concern over state prejudices, the federal interests inherent in the existence of federal habeas corpus jurisdiction make federal abstention unwarranted in cases of state procedural default. Federal abstention in the procedural default/habeas corpus context cannot be justified as a form of Pullman, Burford, or Younger abstention. ${ }^{82}$ Moreover, although the Supreme Court can create additional pockets of federal abstention in circumstances where it feels that judicial deference in the name of comity is more prudent than the exercise of federal jurisdiction, the governmental interests involved in the procedural default/habeas corpus problem do not allow for judicial deference to state interests in the name of some new and independent form of abstention.

A. Judicial Deference to State Interests in the Procedural Default/Habeas Corpus Context Cannot Be Justified As Any Recognized Form of Abstention

\section{The Irrelevance of Pullman Abstention}

The declination to review procedurally defaulted habeas corpus claims cannot be justified as a form of Pullman abstention. Pullman abstention is premised upon the avoidance of both premature constitutional adjudication and unnecessary federal/state friction. In the state procedural default context neither of these concerns exists. After a state decision has been rendered and the federal defense has been defaulted, there is little danger that the federal court's decision on collateral habeas review will merely be an advisory opinion, or in Pullman terms, an unnecessary constitutional decision. ${ }^{83}$ Further, since the only issues of state law have already been decided, there can be no concern as to how a state will interpret its substantive law. Rather, the only state law that

82 As noted, classification of the abstention doctrines is generally an exercise in taxonomy. For purposes of exposition, this comment will use the three most common forms of abstention.

83 Justice Brennan made this point in Murray v Carrier, 477 US 478, 518 n 1 (1987) (Brennan dissenting). 
might occasion any federal/state tension in the context of a procedural default is, by definition, procedural, and has already been employed by the state.

Likewise, there is no problem of avoiding unnecessary friction between the state and federal sovereigns in cases where a federal claim has been defaulted in state court. This is not to say that there is no friction attending the federal release of a state prisoner. Rather, this friction is not "unnecessary" (a Pullman concern) because it is an unavoidable consequence of the habeas corpus statute itself. As Professor Yackle notes, "the institutional settings of state and federal courts make it imperative that the latter have the final word on federal issues."

Indeed, the modern habeas corpus statute contemplates federal relitigation of habeas claims on several levels. First, 28 USC $\S$ 2245 (b) provides that an application for a writ of habeas corpus on behalf of a state prisoner shall not be granted unless that prisoner has exhausted available state remedies. ${ }^{80}$ Thus, federal review is meant to be available as an additional layer of judicial review after exhaustive state court litigation. Second, 28 USC $\S 2254(d)$ provides for extensive relitigation of certain factual questions decided in state court. ${ }^{86}$ Moreover, the Court in Brown $v$ Allen held that state decisions on habeas corpus claims do not act as res judicata on federal review. ${ }^{87}$

In Fay $v$ Noia, the Supreme Court held that the federal courts had a "limited discretion" to decline review in cases of procedural default where the petitioner had deliberately sought to subvert or evade state processes, in part, because 28 U.S.C. $§ 2243$ (1982) allows federal judges, after granting the writ and holding a hearing of appropriate scope, to "dispose of the matter as law and justice require." $\mathrm{But}$, the equitable discretion found in the text of the statute relates to the substantive scope of the writ, and not to the initial assertion of habeas corpus jurisdiction. Judicial discretion to dispose of the case is granted only after granting the writ, or asserting jurisdiction. Hence, any "equity" inherent in the statute seems to speak to remedy, not to the denial of jurisdiction. ${ }^{89}$

${ }^{84}$ Larry W. Yackle, Explaining Habeas Corpus, 60 NYU L Rev 991, 1058 (1985).

${ }^{85}$ For text of 28 USC $\$ 2254(b)$, see note 5 .

${ }^{86}$ See 28 USC $\$ 2254(d)(1)-(8)$.

${ }^{87} 344$ US 443, 458, 460-65 (1953).

${ }^{8 s}$ Fay, 372 US at 438 .

${ }^{89}$ Also, there has been considerable controversy surrounding the scope of the habeas statute. It is unclear whether the statute is coextensive with the scope of the writ at common law. Hence, any discretion inherent in the writ at common law may not necessarily 
The case of Ex parte Royall provides some measure of contemporaneous support for this interpretation. The Royall case was decided in 1885, eighteen years after the Habeas Corpus Act of 1867. Between 1868 and 1885, however, the Supreme Court did not have jurisdiction to decide habeas corpus claims on direct review. ${ }^{90}$ The case thus stands as the first authoritative treatment of the habeas corpus statute in its original form. In the Royall case, the Supreme Court held that the requirement "to dispose of the party as law and justice require ... . does not deprive the court of discretion as to the time and mode in which it will exert the powers conferred upon it."

For the Royall Court, the assertion of federal jurisdiction was not a question of whether, but of when. The federal courts did not have the power to decline jurisdiction altogether, even though its exercise would engender federal/state conflict. The Royall Court noted that after the state court decided a case in question, the federal habeas court could either wait to allow the highest state court to hear the claim or could hear the claim in federal court on habeas review (an option now precluded by the exhaustion requirement of $\S 2254(\mathrm{~b})) .^{92}$ Thus, the federal court could wait to review the federal claim, but it was not allowed to wait forever. Instead, the federal court was held to have the discretion to delay review in order to minimize tensions between the federal and state governments. This delay does less violence to the federal interests inherent in habeas corpus jurisdiction than the "cause and prejudice" test of Wainwright $v$ Sykes, which denies federal review completely in cases of procedural default unless cause and prejudice can be shown for the default.

Moreover, the modern statute requires that, upon application, a judge must award the writ or issue an order directing "the respondent to show cause why the writ should not be granted, unless it appears from the application that the applicant or person detained is not entitled thereto." ${ }^{\text {"93 }}$ Any judicial discretion that exists

exist in the statute. See, for example, Wainwright $v$ Sykes: "For more than a century since the 1867 amendment, this Court has grappled with the relationship between the classical common-law writ of habeas corpus and the remedy provided in 28 USC § 2254." 433 US at 78.

90 From 1868 to 1885 jurisdiction to decide habeas claims had been removed by Congress. The constitutionality of this withdrawal was upheld in Ex parte McCardle, 74 US 506 (1869).

91 117 US 241, 251 (1886) (emphasis added).

92 Royall, 117 US at 253.

os 28 USC § 2243 (1982). 
to decline habeas jurisdiction might be thought to come from these words instead of from the language referring to disposition "as law and justice require." Rule 4 of the rules governing enforcement of the writ of habeas corpus in the federal courts, however, compels a different interpretation.

The Advisory Committee note to the rule explains that the purpose of the "not entitled thereto" language is to place a duty on the federal court to screen out "frivolous" applications from habeas review. ${ }^{94}$ Presumably, "frivolous" in this context means claims by prisoners who are not being held in custody (within the meaning of the statute) or claims of federal law that have already been rejected on the merits. It would have to be a stretch of the language to conclude that an undetermined constitutional claim, as in the case of a procedural default, is "frivolous."

Besides the structure and text of the habeas corpus statute, the legislative purpose behind the extension of the habeas corpus writ, when viewed in its historical context, also shows clearly that federal/state conflict is not "unnecessary" within the meaning of the Pullman abstention doctrine. Extension of the writ in 1867 was necessary to protect federal rights from underenforcement and nullification by the states. ${ }^{95}$ The Habeas Corpus Act of 1867, for example, was presaged by the Habeas Corpus Act of $1833 . .^{96}$ This 1833 Act served as "dramatic precedent for using the writ to enforce unpopular federal laws in the states."

In 1867, Congress did not hesitate to interfere with state court processes. The Thirteenth and Fourteenth Amendments to the United States Constitution, for example, give Congress broad power to enforce their constitutional strictures, power that has

94 See The Committee on Rules of Practice and Procedure of the Judicial Conference of the United States, The Rules Governing 28 USC \& 2254 Cases in the United States District Courts (1976).

${ }^{95}$ See, for example, the opinion of Judge Will in Landry v Daley, 288 F Supp 200, 223 (1968), a § 1983 case, explaining the revolutionary change in federalism caused by the Civil War Amendments:

This revolution, in turn, represents a historical judgment. It emphasizes the overwhelming concern of the Reconstruction Congresses for the protection of the newly won rights of freedmen. By interposing the federal government between the states and their inhabitants, these Congresses sought to avoid the risk of nullification of these rights by the states. With the subsequent passage of the [Civil Rights] Act of 1871, Congress sought to implement this plan by expanding the federal judicial power.

${ }^{98}$ Act of March 2, 1833, ch 57, 7 , 4 Stat 634 , by which the federal courts had jurisdiction "to grant writs of habeas corpus in all cases of a prisoner or prisoners in jail ... by any authority or law, for any act done ... in pursuance of a law of the United States."

${ }^{97}$ Gary Peller, In Defense of Federal Habeas Corpus Relitigation, 16 Harv CR-CL L $\operatorname{Rev} 581,618$ (1982). 
been used and interpreted broadly.$^{98}$ During this period, Congress also passed jurisdictional statutes that funnelled federal question litigation away from state courts..$^{99}$ In addition, broad criminal removal statutes enacted at the time "stood as stark evidence that two years after the Civil War, Congress was not overly wary of interfering with state criminal prosecutions." ${ }^{100}$ Given this history, it seems clear that Congress thought the risk of state nullification of federal rights necessitated infringing upon state judicial processes. ${ }^{101}$

Application of the 1867 Act was meant to be as broad as its language; to "enforce the liberty of all persons ... to enlarge the privilege of the writ of hobeas [sic] corpus, and make the jurisdiction of the courts and the judges of the United States coextensive with all the powers that can be conferred upon them."102 Hence, the scope of federal jurisdiction granted in the Habeas Corpus Act of 1867 must be measured in its historical context; against a backdrop of Reconstruction federalism. ${ }^{103}$ Thus, federal/state friction is

${ }^{98}$ For example, the Civil Rights Act of 1871, which implemented the Fourteenth Amendment, is the precursor of 42 USC $\S 1983$ (1982) which gives a private cause of action to those deprived of federal rights by any person acting under color of state law. For an interpretation of the scope of Congress's enforcement power under the Fourteenth Amendment see Katzenbach v Morgan, 384 US 641 (1966).

9s See Anthony G. Amsterdam, Criminal Prosecutions Affecting Federally Guaranteed Civil Rights: Federal Removal and Habeas Corpus Jurisdiction to Abort State Court Trial, 113 U Pa L Rev 793, 828-842 (1965).

${ }^{100}$ Peller, 16 Harv CR-CL L Rev at 619 (cited in note 97), citing Amsterdam, $113 \mathrm{U} \mathrm{Pa}$ L Rev at 839 (cited in note 99).

${ }^{102}$ It could be argued that federal/state friction is no longer "necessary" since the risk of state hostility to federal constitutional rights is not as great as it was during Reconstruction. This argument must be rejected for two reasons. First, the determination that federal habeas jurisdiction should be expansive was made by Congress (pursuant to constitutional authority) and this decision has not been superseded by a later judgment of that body. More importantly, though, the risk of state nullification, while perhaps dormant, is still present. Note the resistance to the enforcement of desegregation as evidenced in cases such as Harrison v N.A.A.C.P., 360 US 167 (1959). In fact, the Supreme Court has recently noted that not all state court judges have been especially sensitive to the protection of those constitutional rights that make criminal convictions more difficult to obtain. See Stone $v$ Powell, 428 US 465, 493 n 35 (1976).

${ }^{102}$ Cong Globe, 39th Cong, 1st Sess 4151 (July 25, 1866) (Statement of Rep Lawrence.) For a contemporary judicial construction of the scope of habeas jurisdiction, see Ex parte Royall: "The grant to the Circuit Courts in $\$ 751$ of jurisdiction to issue writs of habeas corpus, is in language as broad as could well be employed." 117 US at 247.

${ }^{105}$ For a thorough examination of the relevant history see Peller, 16 Harv CR-CL L Rev at 610-62 (cited in note 97); Robert J. Kaczorowski, Revolutionary Constitutionalism in the Era of Civil War and Reconstruction, 61 NYU L Rev 863 (1986); William M. Wiecek, The Reconstruction of Federal Judicial Power, 1863-1875, 13 Am J Legal Hist 333 (1969).

While the Reconstruction era has long passed, the structure of Reconstruction federalism remains viable as "there has been no alteration of the congressional intent to make the 
not "unnecessary" to the enforcement of the writ of habeas corpus. Because there is no possibility of premature constitutional adjudication in the case of a state procedural default and because concerns over federal/state conflict were specifically rejected by the grant of habeas corpus jurisdiction, Pullman abstention is not an appropriate method for dealing with the procedural default of such claims.

\section{The Irrelevance of Burford Abstention}

The declination to review procedurally defaulted habeas corpus claims cannot be justified as a form of Burford abstention either. The Burford decision was premised primarily upon a desire to avoid technical error in deciding state regulatory questions and an attendant worry about the possible frustration of state regulatory policy. In Burford, the complicated state administrative scheme involved the regulation of oil and gas. In Alabama Public Service Comm'n v Southern Ry. Co., ${ }^{104}$ the Supreme Court took Burford a step farther, denying federal review over a question that concerned the regulation of intrastate railroad service on the grounds that the determination of such rates was a local concern.

The policies behind Burford abstention are inapplicable to the problem of state procedurally defaulted habeas corpus claims because the scheme at issue in a procedural default is the procedural structure of a state's criminal justice system. A system of criminal procedure is not especially complex. At least, it is no more complex than a comparable federal system. Since the state procedural rule has already been applied, there can be no problem of technical error over complex local issues. Instead, federal review of procedurally defaulted claims amounts to a rejection of the state rule. While it is true that there may be some frustration of state policy in disregarding a state procedural default, any frustration comes from the availability of federal relief on habeas corpus and is a byproduct of the habeas statute itself.

\section{The Irrelevance of Younger Abstention}

Younger abstention, with its direct focus upon comity and upon the federal interest in having independently functioning

federal courts the primary protector of the legal rights secured by the Fourteenth and Fifteenth Amendments and the Civil Rights Acts." Harrison, 360 US at $181 \mathrm{n}$ * (1959) (Douglas dissenting).

104341 US 341 (1951). 
states, appears at first glance to provide the correct abstention model for use in resolving the procedural default/habeas corpus problem. In Fay, Francis, and Wainwright, the Supreme Court relied on some conception of comity to bar the hearing of habeas claims that had not been heard in state court due to procedural default. But federal law is paramount under the Supremacy Clause of the United States Constitution. ${ }^{105}$ Hence, "federal law operates of its own force upon and within the states and does not depend upon the willingness of state authorities to accept it."106 Moreover, as Professor Althouse has noted, "[s]tates are not inviolable spheres of sovereignty." They "cannot claim an entitlement to separateness" because a state has only that power which remains after Congress has finished exercising its own Article I power. ${ }^{107}$ Consequently, "comity" in the context of federal/state relations is not a comity of co-equal, but of coordinate sovereigns. This is not to say that the Constitution demands federal jurisdiction over all collateral state claims, but that supremacy must be an element in the balance of state and federal interests.

Additional supremacy parallels can be drawn to federal decisions on state "door-closing" statutes. Even under the Erie doctrine, ${ }^{108}$ a federal court can hear a federal claim regardless of the fact that a state court has validly closed its doors (much like the effect of a procedural default) to such a suit. ${ }^{109}$ In Szantay $v$. Beech Aircraft, Inc. ${ }^{110}$ for example, the Fourth Circuit ruled that the policy embodied in the state "door-closing" statute (which precluded suits brought against a foreign corporation by nonresidents unless the cause of action arose within the state) was outweighed, in part, by the federal policy of avoiding discrimination in state court and the policy of maximum enforcement of the rights of coordinate sovereigns. The same arguments can be made in the procedural default context.

${ }^{105}$ US Const, Art VI.

${ }_{108}$ Yackle, Postconviction Remedies $\S 54$ at 236 (cited in note 84).

${ }^{107}$ Ann Althouse, How to Build a Separate Sphere: Federal Courts and State Power, 100 Harv L Rev 1485, 1485-86 (1987), citing Garcia v San Antonio Metropolitan Transit Authority, 469 US 528 (1985).

${ }^{108}$ Erie R.R. Co. v Tompkins, 304 US 64 (1938).

${ }^{109}$ See Holmberg $v$ Ambrecht, 327 US 392 (1946) (a suit to enforce a federal claim in a federal forum is not controlled by the forum state's statute of limitations); Angel $v$ Bullington, 330 US 183 (1947) (where the state court has closed its doors to a particular kind of suit, a similar suit is barred in a federal court on diversity since the federal court must follow the policy of the forum state). But note Hanna $v$ Plumer, 380 US 460, 469 (1965) (distinguishing a case where "application of the state rule would wholly bar recovery.").

110593 F2d 572 (4th Cir 1979). 
With respect to the abstention of procedurally defaulted habeas corpus claims, the use of judicial discretion to restrict federal jurisdiction on comity grounds is especially inappropriate. As noted above, a "scrupulous regard"111 for state independence was specifically undermined by the extension of federal habeas corpus review to the claims of state prisoners during Reconstruction. ${ }^{112}$ The federal interest involves a "clear congressional policy of affording a federal forum for the determination of the federal claims of state criminal defendants ...."113 Hence, deference in the name of comity, and Younger abstention, has been implicitly rejected by the policies underlying the congressional grant of habeas corpus jurisdiction over state prisoners. ${ }^{114}$

In Ex parte Royall, the Court held that comity dictated that the federal courts should wait to hear a federal claim until the state proceeding was over, but the federal court still had the power to discharge a state prisoner from custody. In Royall, comity was thought to be prudent because the states are also charged with the duty to protect federal rights. In addition, the federal government could always intervene later, if necessary. However, if a state procedural default is given effect in federal court, the federal government will not be in a position to protect a prisoner's constitutional rights later since the constitutional claim will never be heard. The denial of jurisdiction is different from a delay in the exercise of jurisdiction. The denial of jurisdiction completely compromises the federal interests in the enforcement of federal rights in a federal forum.

There are two additional reasons why Younger does not provide a perfect model for abstaining in the procedural default/ habeas corpus context. First, the procedural posture in Younger abstention cases is crucial. As a result of Younger, the federal courts are not generally allowed to enjoin an ongoing state criminal proceeding. This holding does not speak to whether federal courts can hear federal claims after all state proceedings have been exhausted, as on habeas review. The intrusion into state interests is

111 Pullman, 312 US at 501.

112 The extension of the protection of habeas corpus jurisdiction to state prisoners was passed at the peak of Radical Republican power. As an additional avenue of review independent of direct Supreme Court review, it was designed to fight resistance to Reconstruction and help enforce the Reconstruction Amendments. See Fay v Noia, 372 US 391, 415-417 (1963).

${ }^{113}$ Id at 418, citing Ex parte Royall, $117 \mathrm{US}$ at 253.

${ }_{114}$ See Donald H. Ziegler, A Reassessment of the Younger Doctrine in Light of the Legislative History of Reconstruction, 1983 Duke L J 987 (1983). 
much greater in cases of injunction than in habeas review. Second, the substantive claim in Younger was based on the First Amendment. In the habeas corpus context, however, the habeas corpus statute itself specifically authorizes the relitigation of federal claims, something the First Amendment does not. Hence, Younger also fails as a method for resolving the problem raised by the state procedural default of habeas corpus claims.

B. The Inappropriateness of a New Form of Abstention in the Procedural Default/Habeas Corpus Context

Though the federal courts cannot base the abstention of procedurally defaulted habeas corpus claims on any existing abstention doctrine, the question remains whether some new form of federal abstention is appropriate. Federal abstention is an "extraordinary and narrow" prudential limitation on the exercise of statutorily granted jurisdiction. The narrowness is mandated by a federal court's duty "to adjudicate a controversy properly before it"11s because abstention allows the federal courts, in the name of prudential limitation, to do something only Congress is empowered by the Constitution to do: restrict the scope of federal jurisdiction. ${ }^{116}$ Hence, a federal court should only abstain from hearing a case on federalism grounds when the reasons for abstention are clear and unobjectionable; ${ }^{117}$ when respecting the independent functioning of the states is mandated by congressional intent (implicit in the jurisdictional grant) or by constitutional design.

As noted above, the Supreme Court has had trouble articulating a consistent resolution to the problem of procedurally defaulted habeas corpus claims. This difficulty has arisen largely because the Court has been framing and analyzing the question

11 Allegheny County v Mashuda Co., 360 US 185, 188 (1959).

116 See Paul M. Bator, et al, Hart and Wechsler's The Federal Courts and the Federal System 362-478 (Foundation, 3d ed 1988). But see Althouse, $100 \mathrm{Harv}$ L Rev at 1486 (cited in note 107), noting that "[a]lthough Congress initially prescribes the jurisdiction of the federal courts, the courts themselves find extensive room for interpretation of these grants of jurisdiction" (citations omitted).

217 It has been argued that any kind of prudential abstention is unconstitutional on separation of powers grounds. See Cohens $v$ Virginia, 6 Wheat 264, 404 (1821). But Congress has accepted (and, in most cases, even acquiesced in) judicially created prudential limitations upon jurisdiction. Examples include the prudential limitations on standing as well as the judicially developed requirement of exhaustion of state remedies, only later codified by statute. The exhaustion requirement is codified at 28 USC § 2254(b). This is not to say that federal abstention may not be unconstitutional, only that Congress appears to have accepted prudential limitations on federal jurisdiction. For a discussion of the separation of powers problems attending federal abstention see the articles cited in note 56. 
incorrectly. As Professor Bickel realized, "[n]o answer is what the wrong question begets."118 The Supreme Court's confusion has been exacerbated by the extensive discretion it has read into the writ, a discretion that has given the Court the freedom to change its reasoning and emphases without much constraint or explanation.

As a form of abstention, the "cause and prejudice" test adopted in Wainwright, which now governs the analysis of state procedurally defaulted habeas corpus claims, should be evaluated in light of developed abstention standards. The abstention doctrines evolved by the Supreme Court to date are all premised on comity, upon a respect for proper federal/state relations. ${ }^{119}$ However, under the abstention model, declination of federal jurisdiction is only rarely appropriate, and only proper where an important countervailing state interest is served. ${ }^{120}$ The state interest, that is, must outweigh the corresponding federal interest where the two sets of governmental interests actually conflict.

Thus, explicit in the abstention model is the need to identify and balance the various governmental interests involved. Interest analysis is the most basic requirement, and premise, of an abstention doctrine grounded in the judicial allocation of power between sovereigns. When an analysis of the state and federal interests involved in the procedural default of habeas corpus claims is undertaken, the inappropriateness of abstention becomes clear. The Supreme Court has erred in deciding the procedural default/habeas corpus question because it should have been asking, as in the case of any purported conflict, the following two questions: (1) What governmental interests are implicated by the procedural default/ habeas corpus problem? (2) And, given these governmental interests, is there a true conflict between them that would be exacerbated by collateral federal review? Instead, the Supreme Court has been assuming that there is a conflict in cases of state procedural default of habeas corpus claims simply because the state and fed-

${ }_{118}$ Alexander M. Bickel, The Least Dangerous Branch 103 (Bobbs-Merrill, 1960).

110 Colorado River Water Cons. Dist. v United States, 424 US 800, 817 (1976). In Colorado River, the Supreme Court recognized other principles, besides abstention, that might lead a federal court to decline jurisdiction. These principles rest on "[w]ise judicial administration, giving regard to conservation of judicial resources and comprehensive disposition of litigation." Id at 817, citing Kerotest Mfg. Co. v C-O-Two Fire Equipment Co., 342 US 180, 183 (1952). Given the availability, however, of habeas corpus as a form of collateral, postconviction review, an undue emphasis on "the comprehensive disposition of litigation" would seem to be misplaced.

${ }^{120}$ Colorado River, 424 US at 813, citing Allegheny County, 360 US at 188-189. 
eral interests differ.

The federal interests in reviewing habeas corpus claims are both substantive and procedural. From a procedural standpoint the federal interests implicated by federal habeas corpus review-along with the civil rights guaranteed by the Fourteenth Amendment-act as safeguards in state criminal trials. The extension of the writ of habeas corpus to the claims of state petitioners was, like other civil rights legislation passed in connection with Reconstruction federalism, necessitated by a mistrust of state court treatment of federal civil rights claims. The substantive federal interest involved in the federal review of habeas corpus claims lies independently in the vindication of civil and constitutional rights in a federal forum. ${ }^{121}$

The state interests in the procedural default of habeas corpus claims are, however, almost purely local. In Wainwright $v$ Sykes, the Court identified two trial interests, besides respecting the rules of a coordinate jurisdiction qua jurisdiction, served by the state's contemporaneous objection rule. These interests are finality and reliability. But an emphasis on the finality of judicial decisions would seem to be misplaced in the habeas corpus context. As a form of collateral review, its availability undercuts the finality of a state decision by definition.

The Wainwright Court was also wrong in its assessment of the reliability problems attendant to meaningful collateral review of procedurally defaulted habeas corpus claims. In Wainwright, the Supreme Court was very worried that the Fay Court's "deliberate bypass" rule would encourage "sandbagging." The Supreme Court's concern is hard to fathom. "Sandbagging" is defined as "deceiv[ing] (an opponent), as by deliberately playing poorly." 122 Most procedural defaults, however, occur through inadvertence on

122 According to the Younger doctrine, there is an independent federal interest in having the states function independently and in having the states follow and apply federal law. Younger, 401 US at 44. Professor Althouse has argued that this federal interest is derived from the state's duty of day to day criminal adjudication, through federal and state constitutional law as interwoven by incorporation of the Bill of Rights, and from the greater protection of civil liberties that might arise from state freedom to diversify and experiment. Althouse, 100 Harv L Rev at 1508-1509 (cited in note 107). However, if the interest is federal, it is a general federal interest. Habeas corpus review, on the other hand, represents a more specific federal interest premised upon distrust (i.e., judicial interference, not deference) and upon federal courts used as a judicial check. The specific interest should trump the general. Furthermore, the classification of the interest as state or federal is not important and represents another exercise in taxonomy. The interests premised upon independently functioning states should simply be compared to other governmental interests implicated by the procedural default of habeas corpus claims.

${ }^{122}$ Webster's New World Dictionary 1260 (William Collins, 1979). 
the part of appointed or volunteer counsel operating under severe resource constraints. A death penalty authority recently noted, for example, that "the frequent reason why these [constitutional habeas] claims are not raised earlier . . . [is] because harried, inexperienced, time-pressured, underpaid or unpaid trial counsel and volunteer habeas counsel fail to recognize, preserve, and raise many meritorious constitutional claims." 123 Defaults that occur under these circumstances are not intentional; they do not constitute "sandbagging".

In addition, it seems extremely doubtful that imposing the cost of default on a defendant will act to deter default by an attorney. This is so because it is the defendant, not the lawyer, who bears the cost of the lawyer's mistakes. The defendant, having comparatively less legal knowledge than his attorney-and having even fewer resources-is not in a position to catch his attorney's mistakes or pass the costs of the default onto his attorney. This is especially true given that the standards for ineffective assistance of counsel under Strickland $v$ Washington are very hard to meet. ${ }^{124}$

Hence, the Supreme Court's belief that the "deliberate bypass" rule would encourage "sandbagging" is patently incorrect. ${ }^{126}$ Procedural defaults caused by inadvertence of counsel, and attributed to the defendant, will not be any more discouraged by the "cause and prejudice" rule than by the "deliberate bypass" rule. Truly intentional defaults (i.e., sandbagging) would have, in fact, been covered by definition under Fay's "deliberate bypass" rule, a rule that was designed specifically to deter and catch the intentional subversion and evasion of state processes.

Once the finality and reliability concerns have been dispelled, the only state interest served by the federal abstention of habeas corpus claims defaulted in state court is one of comity: deferring to the states in their enforcement of local, substantive criminal law. It is true that procedural rules are designed to facilitate the enforcement of state substantive law, but once it is recognized that the "sandbagging" problem is unreal, ${ }^{126}$ an interest analysis of the pro-

${ }^{123}$ Ronald J. Tabak, The Death of Fairness: The Arbitrary and Capricious Imposition of the Death Penalty in the 1980's, 14 NYU Rev L \& Soc Change 797, 842 (1986).

124466 US 668 (1984).

125 For a refutation of the Wainwright majority's sandbagging concerns and a discussion of inadvertent defaults see Justice Brennan's dissent. 433 US at 100-05.

${ }^{128}$ Even if the problem of "sandbagging" is not unreal, it remains that, by giving federal effect to a state procedural default, "[t]he goal of protecting the state rule of procedure is thus attained through the sacrifice of rights guaranteed by the Constitution. Such an exaltation of procedure over substance is virtually impossible to justify. Compliance with 
cedural default/habeas corpus issue no longer is answered with a federal/state conflict:

Positing that prior state court litigation is required primarily to maintain local control of the substantive criminal law, and given the incentives that litigants have to raise federal claims anyway, there is no reason why litigants' ultimate opportunity to pursue federal claims in the federal forum should be freighted with mechanisms for enforcing state procedural rules. ${ }^{127}$

Framing the issue in this way gives a clearer picture of the governmental interests involved in the problem of procedurally defaulted habeas corpus claims and shows that there is no conflict between the state and federal interests, since federal "[a]bdication of the obligation to decide cases can be justified under this doctrine only in the exceptional circumstances where the order of the parties to repair to the State court would clearly serve 'an important countervailing interest." "128 If the state interest lies chiefly in the enforcement of local substantive criminal law through procedural rules, and the federal interests involved are wholly different-the federal interest being both substantive (i.e., vindication of both civil and constitutional rights) and procedural (i.e., habeas corpus as a procedural safeguard) - and federal review is available as a discrete supplement to state review in appropriate circumstances, there actually is no federal/state conflict presented by the federal review of state procedurally defaulted habeas corpus claims.

This is so because the finality of state court litigation has been specifically undercut by the availability of collateral federal review under the habeas corpus statute. Under the statute, the state court is allowed to review the federal claim first, but the state decision on the federal claim is not dispositive where a cognizable habeas corpus claim exists. Hence, a state does not have a legitimate governmental interest in the complete finality of its decisions over habeas corpus claims. Since the state has no "countervailing" interest that would be fostered by the declination of federal jurisdiction in cases of state procedural default, the federal courts should

rules of procedure is never an end in itself." Curtis R. Reitz, Federal Habeas Corpus: Impact of An Abortive State Proceeding, 74 Harv L Rev 1315, 1350 (1961). The author goes on to suggest that less severe sanctions be created to give some force to the state procedural default.

${ }_{127}$ Yackle, 60 NYU L Rev at 1058-1059 (cited in note 84).

${ }^{128}$ Colorado River, 424 US at 813, citing Allegheny County, 360 US at 188-89. 
not abstain from hearing such claims. ${ }^{129}$

\section{Conclusion}

Wainwright $v$ Sykes is wrong. The decision to respect state procedural rules "both for the fact that [they are] employed by a coordinate jurisdiction within the federal system and for the many interests which [they] serve[] in [their] own right"130 cannot be justified as a form of abstention. The state interest in fostering the procedural integrity of criminal trials simply does not overcome the heavy presumption against a federal court's "virtually unflagging obligation"131 to exercise civil rights jurisdiction granted by Congress.

This is especially true if one realizes that, in the context of a procedurally defaulted habeas claim, a state actually has no convincing "countervailing interest" in the protection of its procedural system. Hence, the refusal of federal habeas corpus jurisdiction on account of a procedural default amounts to an unwarranted form of abstention. Simply put, "[i]t should be unnecessary to repeat what so often has been said and what so plainly is the case: that the availability of the Great Writ of habeas corpus in the federal courts for persons in the custody of the States offends no legitimate state interest in the enforcement of criminal justice or procedure."132

${ }^{129}$ Further, Professor Yackle has noted that in many cases it would probably be less costly, in terms of judicial resources, to decide the merits of procedurally defaulted habeas corpus claims than to decide what the consequences of procedural defaults should be in particular cases. Yackle, 60 NYU L Rev at $1059 \mathrm{n} 281$ (cited in note 84).

130 Wainwright, 433 US at 88.

131 Colorado River, 424 US at 817 (citations omitted).

${ }^{132}$ Fay, 372 US at 440. 